\title{
三点両角法による船位測定について
}

\section{Study on the Determindtion of Ship's Position by the Horizontal Sextant Angles Method \\ 本岩節 (北海道大学水産学部)}

\begin{abstract}
For many years, navigaters have believed that they can get exact ship's position by Horizontal Sextant Angles Method. However, the basis of its argument is very superficial and they have not theoretically considered about the selection of land objects. To solve this problem and apply it in practice, the writer analysed some cases as to which ones to be preferably selected from many objects to get a fix at ship. And further, he treated of the fundamentl comparison and examination of the probability densities of ship's fosition gotten by this methed and Cross Bearing Method, and descrited the matters that demand special attention.

He believes that this fundamental study contributes to the practical selection of land objects and hopes the significance of the exact method to be fully acknowledged.
\end{abstract}

\section{I. ま え が き}

与えられを三物標の 2 つの水平夾看を六分儀で測定して求めを船位の確らしさにつんては，既

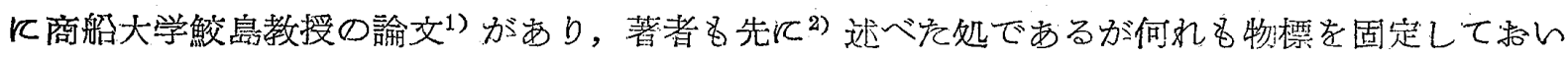

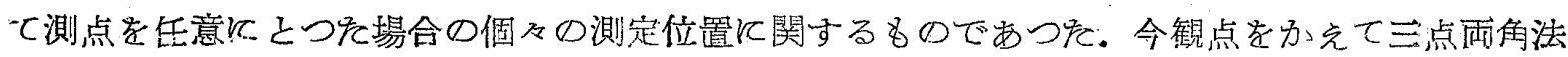
とん5船位測定の方法よりみれば問題とをるのは固定されそ測点に於て如何をる物標を選択すべ きかといらととである，本稿て於てはその解明のをめ或る条件下に於て物標を任意に選択しうる るのとして若干の場合炕つき解析してみをん。

\section{II. 物標がー直線上に存在する場合}

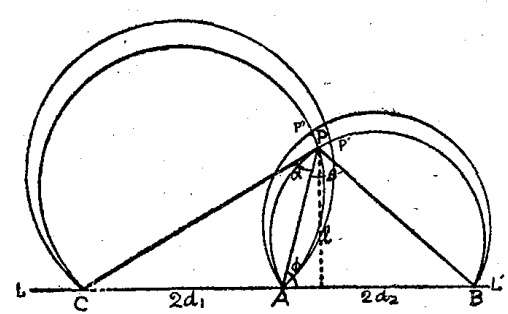

Fig. 1

Fig. 1 K於て測点を $P$ とし定㨁線 $L L^{\prime}$. 上飞無数に物標が存 在するものとする，P上り $L L^{\prime}$ 沉至る垂直目離を $l, L L^{\prime}$ 上 飞任意飞三物標 $\mathrm{A}, \mathrm{B}, \mathrm{C}$, をと $b$ 二水平夾角 $(\alpha, \beta)$ 得て耐㧓の交点として求められた。今 $A C=2 d_{1}, A B=$ $2 d_{2}, \angle A P C=\alpha, \angle B P A=\beta, \angle P A B=\phi$ 工符号定つけ $\angle \beta$ Constant として測角 $\alpha$ そ $\Delta \alpha$ の誤差があるとを両 円弧の交点を $P^{\prime}$ 亡すれば

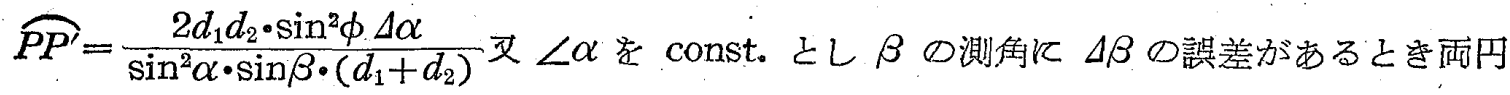

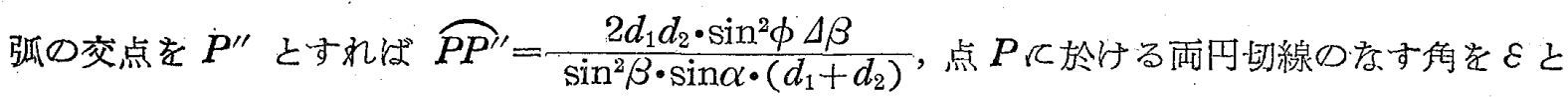
すれば交点 $P$ の確率密展 $(g)$ は， $g=\frac{\sin \varepsilon}{2 \pi \sigma_{1} \sigma_{2}}$ そ表はされる，但し $\sigma_{1} ， \sigma_{2}$ は交点の周りに 
於ける両位置の線の標準偏差である。今静止の一点於て両観測考行つたのであれば

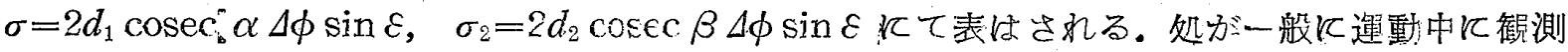

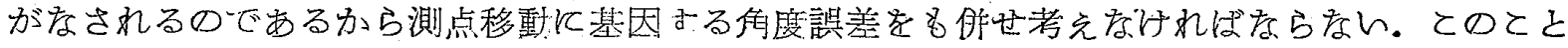
は物標に近ん程一般飞顕著であり，物標の配置と測点の移勳方向，巨離によつて当然变化する量

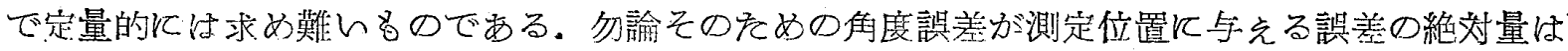

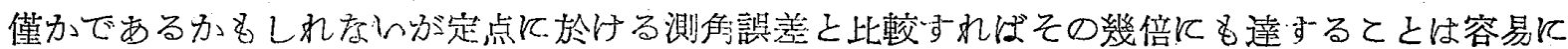

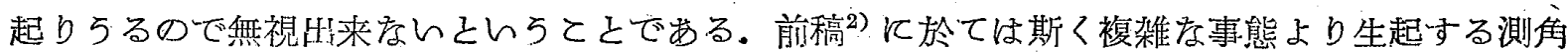

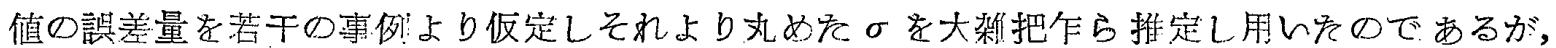
客観性, 普遍性の点に於て父ける5らみがあるので本稿飞於ては張角 $\alpha, \beta$ 偲ば静止の一点K 於て観測し得られをものであるとの仮是家設けを。

斯くすれば

$g=\frac{\sin ^{3} \alpha \cdot \sin ^{3} \beta\left(d_{1}+d_{2}\right)^{2}}{8 \pi d_{1}{ }^{2} d_{2}^{2} \cdot \sin ^{4} \phi \cdot \sin (\alpha+\beta) \Delta \alpha \Delta \beta} k$ 表梳される. 之に. $d_{1}=\frac{l \sin \alpha}{2 \sin \phi \cdot \sin (\phi-\alpha)}$, $d_{2}=\frac{l \sin \beta}{2 \sin \phi \cdot \sin (\phi+\beta)}$ を代入すれば $g=\frac{\sin \alpha \cdot \sin \beta\{\sin \alpha \cdot \sin (\phi+\beta)+\sin \beta \cdot \sin (\phi-\alpha)\}^{2}}{2 \pi l^{2} \cdot \sin (\alpha+\beta) \sin ^{2} \phi \cdot \Delta \alpha \Delta \beta}$

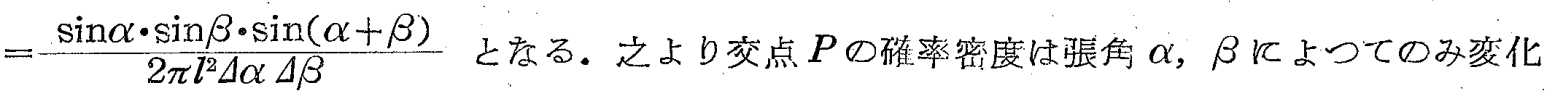

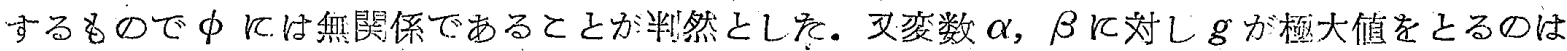
$\alpha=\beta=60^{\circ}$ の場合であつてそのときの $g^{\prime}=3 \sqrt{3} / 8$ である.（但し $g^{\prime}=2 \pi l^{2} \Delta \alpha \Delta \beta \cdot g$.)

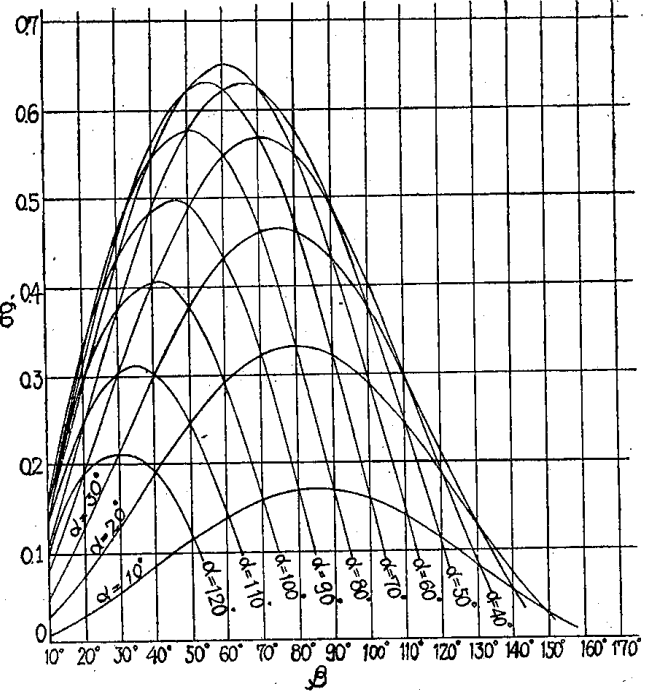

Fig 2

刃一角 $\alpha$ が常数なるとを变数 $\beta$ 凡刘し $g$ が極大 となるのは $\beta=90^{\circ}-\alpha / 2$ のきでその膓合の $g^{\prime}=$

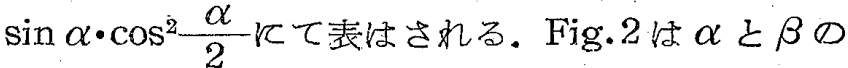
組合せをよる $g^{\prime}$ の変化状沉を画んをるのである。

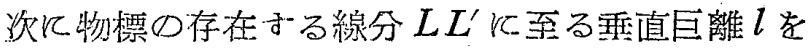
変数亡扱つてみよう。測点上り $L L^{\prime}$ 飞至る 巨離が $l$ なる場合の $g$ の極大值は $\alpha=\beta=60^{\circ}$ の昜合の $\frac{0.6495}{2 \pi l^{2} \Delta \alpha \Delta \beta}$ であつを. (之を $g_{1}$ とす) 今測点よbの 目離が $l^{\prime}\left(\right.$ 但し $\left.l^{\prime}<l\right)$ ）学る線分上て物標を選んだ場 合 $g_{1}$ 上り大索る $g$ をとりうる簛囲を求めてみる。 そФ関係蛅容易飞 $\sin \alpha \cdot \sin \beta \cdot \sin (\alpha+\beta)>0.6495$ $\left(\frac{l^{\prime}}{l}\right)^{2}$ として求められる。今問題学簡単にするをめ

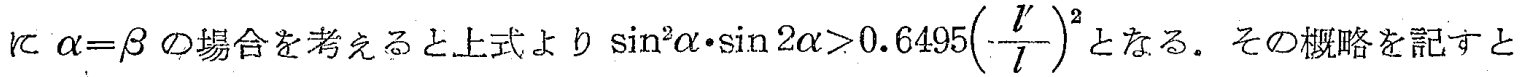

Table 1 の如くである.

Table 1

\begin{tabular}{|c|c|c|c|c|c|c|c|c|}
\hline$l^{\prime} / l$ & 0.9 & 0.8 & 0.7 & 0.6 & 0.5 & 0.4 & 0.3 & 0.2 \\
\hline$\alpha=\beta$ & $72^{\circ} \sim 47^{\circ}$ & $77^{\circ} \sim 41^{\circ}$ & $80^{\circ} \sim 36^{\circ}$ & $83^{\circ} \sim 31^{\circ}$ & $85^{\circ} \sim 27^{\circ}$ & $87^{\circ} \sim 23^{\circ}$ & $88^{\circ} \sim 19^{\circ}$ & $89^{\circ} \sim 14^{\circ}$ \\
\hline
\end{tabular}

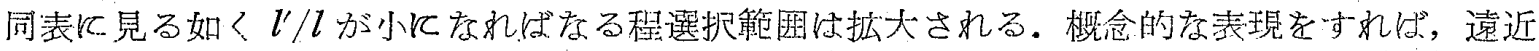
無数に物:標が存在する場合には鬼に角近いものを選ぶことである。 


\section{III. 物標が同一円周上にある場合}

Fig. 3 の如く測点 $P$ を中とし $l$ 半径とする円周上飞物標が存在するるのとし前項と同様 飞誤差を含已円弧の交点を $P^{\prime}, P^{\prime \prime}$ とすれば

$$
\overparen{P P^{\prime}}=\frac{2 l \Delta \alpha \sin \frac{\alpha}{2} \cdot \cos ^{2} \frac{\alpha}{2} \cdot \sin \frac{\beta}{2}}{\sin \beta \cdot \sin ^{2} \alpha\left\{\sin \frac{\alpha}{2}+\sin \frac{\beta}{2} \cos \frac{1}{2}(\alpha+\beta)-\sin \frac{\beta}{2} \cot \beta \cdot \sin \frac{1}{2}(\alpha+\beta)\right\}}
$$$$
=\frac{l \Delta \alpha}{2 \sin \frac{\alpha}{2} \cdot \sin \frac{1}{2}(\alpha+\beta)}
$$

また $\overparen{P P^{\prime \prime}}=\frac{2 l \sin \frac{\alpha}{2} \cdot \sin \frac{\beta}{2} \cdot \cos \frac{\alpha}{2}\left\{\cos \frac{\alpha}{2} \cdot \cos \frac{1}{2}(\alpha+\beta)+\sin \frac{\alpha}{2} \cdot \sin \frac{1}{2}(\alpha+\beta)\right\} \Delta \beta}{\sin ^{2} \beta \cdot \sin \alpha\left\{\sin \frac{\alpha}{2}+\sin \frac{\beta}{2} \cdot \cos \frac{1}{2}(\alpha+\beta)-\sin \frac{\beta}{2} \cot \beta \cdot \sin \frac{1}{2}(\alpha+\beta)\right\}}$

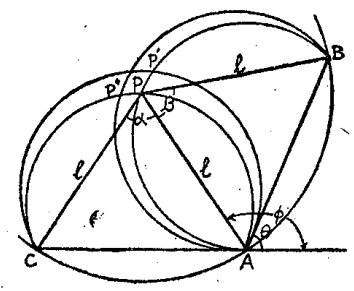

Fig. 3

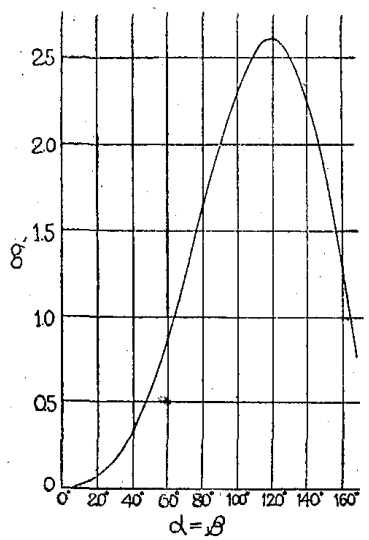

Fig. 4

$$
=\frac{l \Delta \beta}{2 \sin \frac{\beta}{2} \cdot \sin \frac{1}{2}(\alpha+\beta)}
$$

従つて $g=\frac{4 \sin \frac{\alpha}{2} \cdot \sin \frac{\beta}{2} \cdot \sin \frac{1}{2}(\alpha+\beta)}{2 \pi l^{2} \Delta \alpha \cdot \Delta \beta}$ 変数 $\alpha, \beta$ 飞対し $g$ 汃極大となるの社 $\alpha=\beta=120^{\circ}$ の場合でそのときの $g\left[=4 \sin \frac{\alpha}{2} \cdot \sin \frac{\beta}{2} \cdot \sin \frac{1}{2}(\alpha+\beta)\right]$ は $\frac{3 \sqrt{3}}{2}$ である.

Fig. 4 亿二つの脹角 $\alpha, \beta$ が等しんとしを場合の $g$ の值を示し そ. 次江 $\alpha$ が常数の場合，交数 $\beta$ 江対し $g$ 力゙極大值をとる条件は $\beta=180^{\circ}-\frac{\alpha}{2}$ にしてその锡合の $g$ は $4 \sin \frac{\beta}{2} \cdot \cos ^{2} \frac{\alpha}{2}$ にて表はさ れる. この $\alpha, \beta$ の関係及びそのとをの $g^{\prime} の$ 值を表記すれば

\begin{tabular}{|c|c|c|c|c|c|c|c|c|c|c|c|c|c|c|c|c|c|}
\hline$\alpha$ & $10^{\circ}$ & $20^{\circ}$ & $30^{\circ}$ & $40^{\circ}$ & $50^{\circ}$ & $60^{\circ}$ & $70^{\circ}$ & $80^{\circ}$ & $90^{\circ}$ & $100^{\circ}$ & $110^{\circ}$ & $120^{\circ}$ & $130^{\circ}$ & $140^{\circ}$ & $150^{\circ}$ & $160^{\circ}$ & $170^{\circ}$ \\
\hline$\beta$ & $175^{\circ}$ & $170^{\circ}$ & $165^{\circ}$ & $160^{\circ}$ & $155^{\circ}$ & $150^{\circ}$ & $145^{\circ}$ & $140^{\circ}$ & $135^{\circ}$ & $130^{\circ}$ & $125^{\circ}$ & $120^{\circ}$ & $115^{\circ}$ & $110^{\circ}$ & $105^{\circ}$ & $100^{\circ}$ & $95^{\circ}$ \\
\hline$g^{\prime}$ & 0.35 & 0.69 & 1.02 & 1.35 & 1.61 & 1.87 & 2.09 & 2.27 & 2.41 & 2.52 & 2.58 & 2.60 & 2.58 & 2.52 & 2.43 & 2.31 & 2.17 \\
\hline
\end{tabular}
Table 2 の如くである.

\section{IV. 測点が物標の存在する二線分のなす角の二等分線上に在る場合}

Fig. 5 飞於て $P$ を測点, 選んれ゙三物標を $A, C, B$ を五. 但し物標 $B, A$ は $\angle P C A=\angle P C B$ となる直線 $B C, A C$ 上飞存在し壬意飞とりらるるのとす。 今測角 $\alpha, \beta 反 \Delta \alpha, \Delta \beta$ の誤盖があ れば

$$
\overparen{P P^{\prime}}=\frac{l \cos \frac{\theta}{2} \cdot \Delta \beta}{\sin \alpha\left\{\sin \alpha \cdot \cos \left(\beta-\frac{\theta}{2}\right)+\cos \left(\alpha-\frac{\theta}{2}\right) \sin (\beta-\theta)\right\}}
$$




$$
\begin{aligned}
& \overparen{P P^{\prime \prime}}=\frac{l \cos \frac{\theta}{2} \cdot \Delta \beta}{\sin \beta\left\{\sin \alpha \cdot \cos \left(\beta-\frac{\theta}{2}\right)+\cos \left(\alpha-\frac{\theta}{2}\right) \sin (\beta-\theta)\right\}} \\
& \therefore g=\frac{\sin \alpha \cdot \sin \beta \cdot\left\{\sin \alpha \cdot \cos \left(\beta-\frac{\theta}{2}\right)+\cos \left(\alpha-\frac{\theta}{2}\right) \sin (\beta-\theta)\right\}^{2}}{2 \pi l^{2} \Delta \alpha \cdot \Delta \beta \cdot \sin (\alpha+\beta-\theta) \cos ^{2} \frac{\theta}{2}}
\end{aligned}
$$

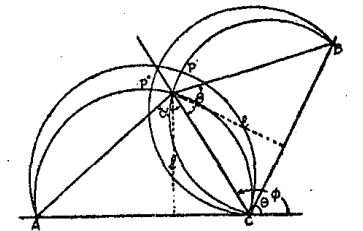

Fig. 5

にて表はされる. 変数 $\alpha, \beta$ 対し之が極值をとるのは $\alpha=\beta$ とて 且つそれ的

$16 \sin ^{6} \alpha-24 \sin ^{4} \alpha+9 \sin ^{2} \alpha-\sin ^{2} \theta=\sin ^{2} 2 \alpha-\sin ^{2} \theta=0$ を满足するる のである. 之上り $\alpha=60^{\circ}+\frac{\theta}{3}$ 及び $\alpha=\frac{\theta}{3}$ 得る. 従つてそのと きの $\left|g_{1}\right|=\frac{\sin ^{3}\left(60^{\circ}+\frac{\theta}{3}\right)}{2 \pi l^{2} \Delta \alpha \Delta \beta}$ 及び $\left|g_{2}\right|=\frac{\sin ^{3} \frac{\theta}{3}}{2 \pi l^{2} \Delta \alpha \Delta \beta}$ である.とてに $g_{1}$ は

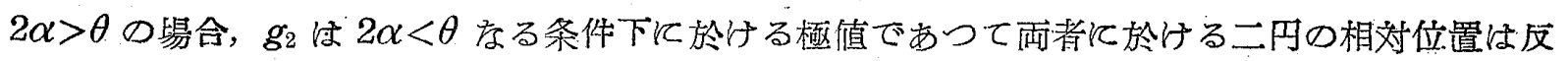
対である。換言す机ば $g_{1}$ と $g_{2}$ 快四点 $(P, A, B, C)$ が同一円周上にある点 $(2 \alpha-\theta=0)$ の

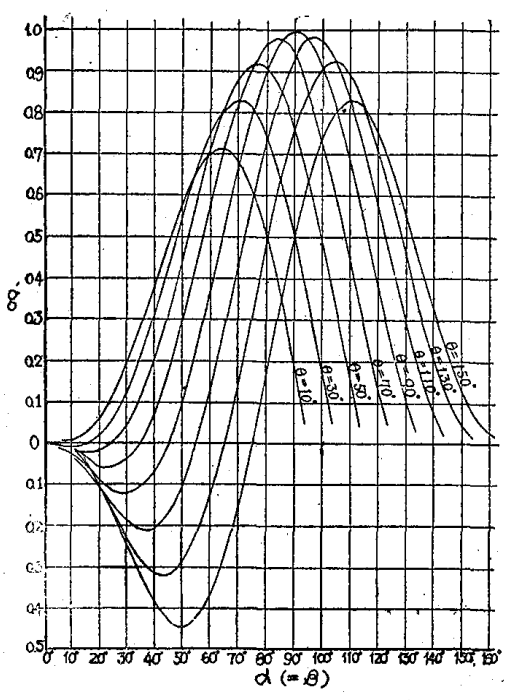

Fig. 6 両側飞存在す。平雨極值をとるときの二问弧の交角は $2 \alpha>\theta$ の場合 $120^{\circ}-\frac{\theta}{3}, 2 \alpha<\theta$ 学る場合忙 $\frac{\theta}{3}$ である. 次に $\left|g_{1}\right|$ と $\left|g_{2}\right|$ の比較であるが $\theta<180^{\circ}$.なる故 $\sin \left(60^{\circ}+\frac{\theta}{3}\right)>$ $\sin \frac{\theta}{3}$ 従つて $\left|g_{1}\right|>\left|g_{2}\right|$ である。战に $2 \alpha>\theta$ なる場合の 極值をとる様な物標劣選択するととが好昰しん，(VD (4) 参照） $\theta$ が変数なるとき $g$ が最大と疗るのは $\theta=90^{\circ}$ ， $\alpha=\beta=90^{\circ}$ なる場合でそのよきの $g=\frac{1}{2 \pi l^{2} \Delta \alpha \Delta \beta}$ である。 Fig. 6 㤌 $\theta=10^{\circ}, 30^{\circ} \cdots \cdot 150^{\circ}$ 度る锡合の $\alpha(=\beta)$ 反対する

$$
g^{\prime}=\frac{\sin ^{2} \alpha\{\sin \alpha+\sin (\alpha-\theta)\}^{2} \cos ^{2}\left(\alpha-\frac{\theta}{2}\right)}{\sin |2 \alpha-\theta| \cos ^{2} \frac{\theta}{2}}
$$

$=\sin ^{2} \alpha \cdot \sin |2 \alpha-\theta|$ 示す. 各 $\theta$ 亿刘する $g$ の最大点を結ぶとしの curveは $\theta=90^{\circ}$. を 夾んで左右対称である。その理由性 $\sin \left(60^{\circ}+\frac{\theta}{3}\right)=\sin \left(60^{\circ}+\frac{180^{\circ}-\theta}{3}\right)$ なるくる.

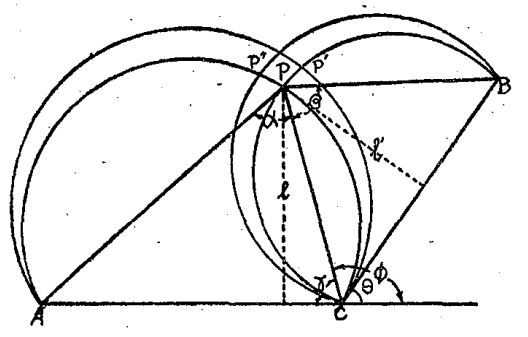

Fig. 7

\section{P が $\angle A C B$ の二等分線上に在らざる場合}

Fig. 7 飞於ける如く測点 $P$ 上り選定し充物標 $A, C ; B$, $C$ 老結ぶ線分飞至る巨離 $l, l^{\prime}$ が等しくをい場合（即ち測点 が物標の存在する二線分のなす解の二等分線上にあらざる場 合)

$\overparen{P P^{\prime}}=\frac{l l^{\prime} \sin \gamma \Delta \alpha}{\sin \alpha\left\{l \sin \alpha \cdot \sin (\gamma+\theta) \sin (\gamma+\theta-\beta) \operatorname{cosec} \gamma+l^{\prime} \sin (\beta-\theta) \sin (\gamma+\alpha)\right\}}$ 


$$
\overparen{P P}^{\prime \prime}=\frac{l l^{\prime} \sin (\gamma+\theta) \Delta \beta}{\sin \beta\left\{l \sin \alpha \cdot \sin (\gamma+\theta) \sin (\gamma+\theta-\beta) \operatorname{cosec} \gamma+l^{\prime} \sin (\beta-\theta) \sin (\gamma+\alpha)\right\}}
$$

従つて $g=\frac{\sin \alpha \cdot \sin \beta\left\{l \sin \alpha \cdot \sin (\gamma+\theta) \sin (\gamma+\theta-\beta) \operatorname{cosec} \gamma+l^{\prime} \sin (\beta-\theta) \sin (\gamma+\alpha)\right\}^{2}}{2 \pi \sin (\alpha+\beta-\theta)\left(l l^{\prime}\right)^{2} \Delta \alpha \Delta \beta \cdot \sin \gamma \cdot \sin (\gamma+\theta)}$

或社 $l^{\prime}=l \operatorname{cosec} \gamma \cdot \sin (\gamma+\theta)$ をる故

$$
g=\frac{\sin \alpha \cdot \sin \beta\{\sin \alpha \cdot \sin (\gamma+\theta-\beta)+\sin (\beta-\theta) \sin (\gamma+\alpha)\}^{2}}{2 \pi l^{2} \Delta \alpha \Delta \beta \sin (\gamma+\theta) \sin \gamma \cdot \sin (\alpha+\beta-\theta)} \text { て表はされる・此の式に於て }
$$

$\alpha, \beta, \gamma, \theta$ 悉く変数亡扱つを場合，夹等の要素が任意の值をとるときの $\mathrm{g}$ 值をすべて求む

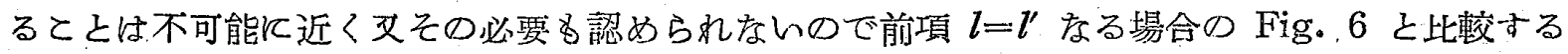
意味に於て $l^{\prime}=2 l$ なる関係があ $b \theta$ が $45^{\circ}, 90^{\circ}$ 素る場合種及の $\alpha, \beta$ の組合世による $g^{\prime} の$

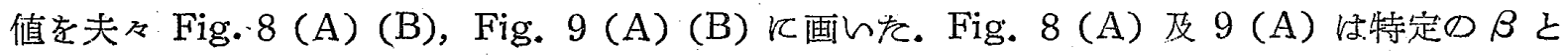

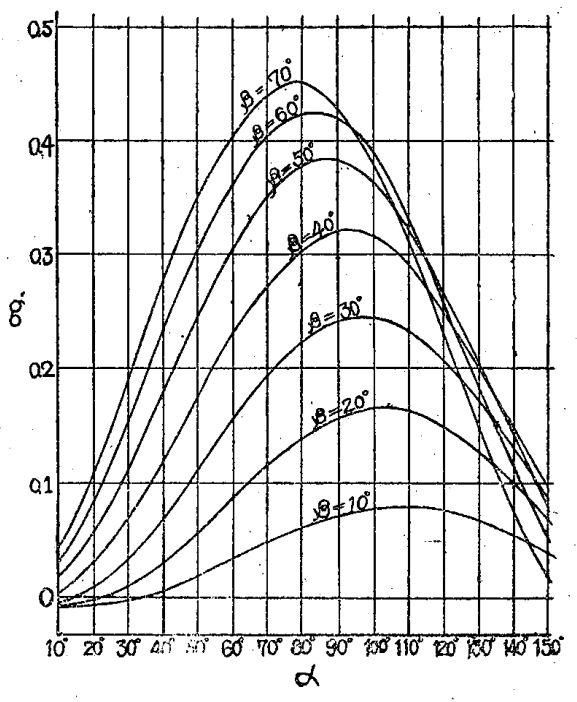

Fig. 8 (A)

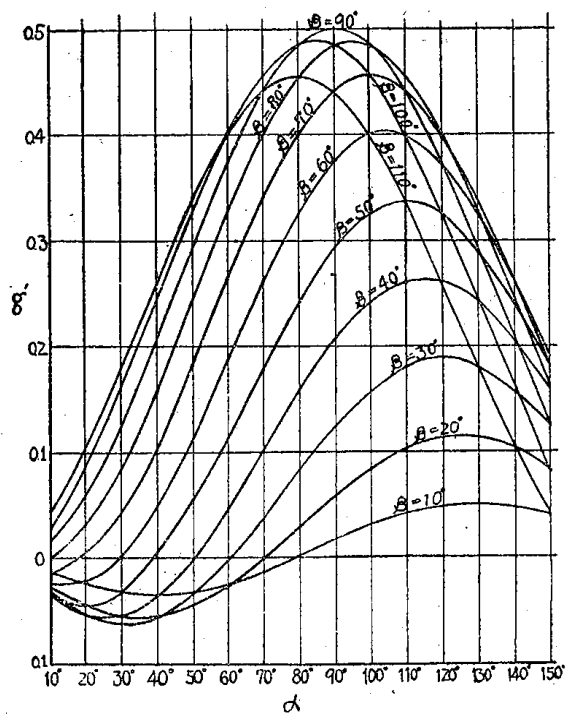

Fig. 8 (A)

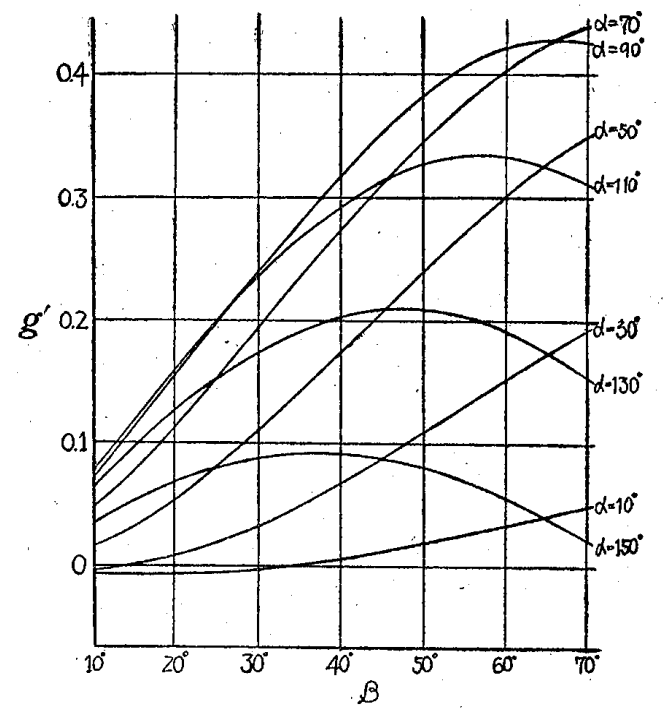

Fig. 8 (B)

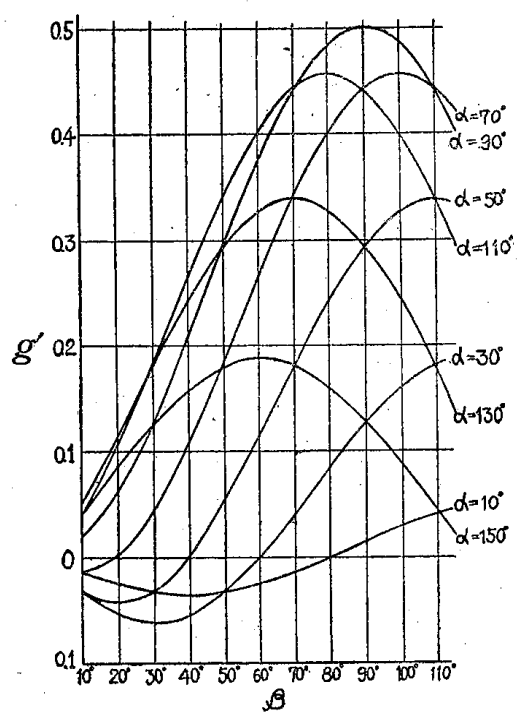

Fig. 8 (B)

壬意の $\alpha$ の組合せ丈 Fig. 8 (B) 及9 (B) は特定の $\alpha$ と任意の $\beta$ の組合せとょるものであ る.

次江 $g$ の極值条件を求好て見よ5. 
（1） $\alpha$ が変数； $\beta, \theta ， \gamma$ が常数なる場合 極值条件壮 $4 \sin ^{6} \alpha-4 \sin ^{4} \alpha\left\{\sin ^{2}(\beta-\theta)+1\right\}+5 \sin ^{2} \alpha \cdot \sin ^{2}(\beta-\theta)-\sin ^{4}(\beta-\theta)=0$ 上り $\alpha_{1}=90^{\circ}-\frac{1}{2}(\beta-\theta)$ 及び $\alpha_{2}=\frac{1}{2}(\theta-\beta)$ を得る。 ここK $\alpha_{1}$ は $\alpha+\beta>\theta$ なる暢合， $\alpha_{2}$ は $\alpha+\beta<\theta$ なるときの求むる值である。従つて与えられ ₹ $\beta, \theta, \gamma$ 《対する $|g|$ の極值は $\frac{\cos ^{2} \frac{1}{2}(\beta-\theta) \sin \beta \cdot \sin \gamma}{2 \pi l^{2} \cdot \sin (\gamma+\theta) \Delta \alpha \Delta \beta}$ 及び $\frac{\sin ^{2} \frac{1}{2}(\theta-\beta) \sin \beta \cdot \sin \gamma}{2 \pi l^{2} \cdot \sin (\gamma+\theta) \Delta \alpha \Delta \beta} \nwarrow \tau$ 表はされる。

(2) $\beta$ が変数； $\alpha, \theta ， \gamma$ が常数をるとを

極值条件的， $\cos ^{6} \beta-\cos ^{4} \beta\left\{4 \sin ^{4} \frac{1}{2}(\alpha-\theta)-4 \sin ^{2} \frac{1}{2}(\alpha-\theta)+2\right\}$

$$
\begin{aligned}
& +\cos ^{2} \beta\left\{3 \sin ^{4} \frac{1}{2}(\alpha-\theta)-3 \sin ^{2} \frac{1}{2}(\alpha-\theta)+1\right\} \\
& +\left\{4 \sin ^{8} \frac{1}{2}(\alpha-\theta)-8 \sin ^{6} \frac{1}{2}(\alpha-\theta)+5 \sin ^{4} \frac{1}{2}(\alpha-\theta)-\sin ^{2} \frac{1}{2}(\alpha-\theta)\right\}=0
\end{aligned}
$$

そより $\beta_{1}=90^{\circ}-\frac{1}{2}(\alpha-\theta)$ 及び $\beta_{2}=\frac{1}{2}(\theta-\alpha)$ を得る。

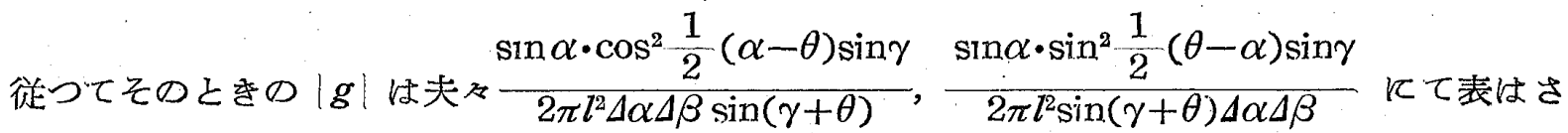
れる。

(3) $\beta, \theta:$ 変数; $\alpha, \gamma$ が常数なるとき

Fig. 7 飞みる如く測点 $P$ に於て既に二物標 $A, C$ をとり他の一物標 $B$ を任意に選ばんと

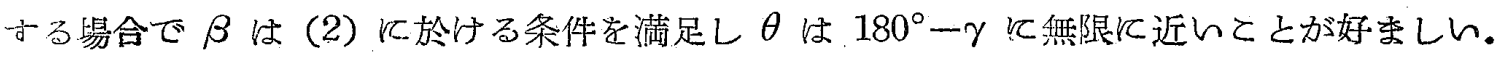

(4) $\alpha, \beta$ : 変数; $\theta, \gamma$ 少常数なるとき

$\frac{\partial g}{\partial \beta}=0$ なる式に $\frac{\partial g}{\partial \alpha}=0$ より得を $\alpha_{1}=90^{\circ}-\frac{1}{2}(\beta-\theta)$ 及び $\alpha_{2}=\frac{1}{2}(\theta-\beta)$ を代入すると $4 \cos ^{4} \beta_{1}+4 \cos ^{3} \beta_{1} \cdot \cos \theta-3 \cos ^{2} \beta_{1}-2 \cos \beta_{1} \cos \theta+\cos ^{2} \theta=0$ 疗び $4 \cos ^{4} \beta_{2}-4 \cos ^{3} \beta_{2} \cdot \cos \theta$ $-3 \cos ^{2} \beta_{2}+2 \cos \beta_{2} \cos \theta+\cos ^{2} \theta=0$ 得る。乙の両式よ $b \quad \beta_{1}=60^{\circ}+\frac{\theta}{3}$ 及び $\beta_{2}=\frac{\theta}{3}$ を求めら れる. 從つてそのとをの $\alpha$ も亦 $60^{\circ}+\frac{\theta}{3}$ 及び $\frac{\theta}{3}$ となる. $\alpha, \beta$ が共て此の值をとるとをの $|\boldsymbol{g}|$ は $\frac{\sin ^{3}\left(60^{\circ}+\frac{\theta}{3}\right) \sin \gamma}{2 \pi l^{2} \Delta \alpha \Delta \beta \sin (\gamma+\theta)}$ 及び $\frac{\sin ^{3} \frac{\theta}{3} \sin \gamma}{2 \pi l^{2} \Delta \alpha \Delta \beta \sin (\gamma+\theta)}$ とて表はされる。故に $\frac{l^{\prime}}{l}$ の值換言すれば $\angle \gamma$ の如何に拘ら亦或る測点に於て $g$ が䄚值をとるのは $\alpha=\beta=60^{\circ}+\frac{\theta}{3}$ 及び $\alpha=\beta=\frac{\theta}{3}$ の 場合である，前項即ち $\frac{l^{\prime}}{l}=1 の$ 場合は本項の特殊な場合に該当し当然同じ結果を示す，次に両極

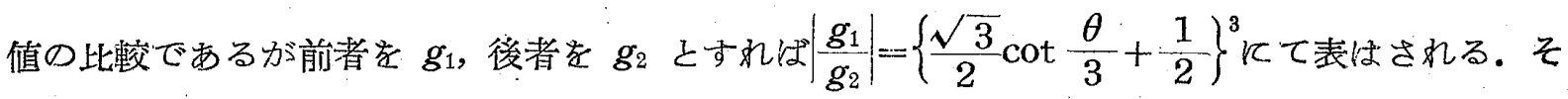
の大要を記すと Table 3 の如?である. 
Table 3

\begin{tabular}{|c|c|c|c|c|c|c|c|c|}
\hline$\theta$ & $10^{\circ}$ & \multicolumn{1}{c|}{$30^{\circ}$} & $50^{\circ}$ & $70^{\circ}$ & $90^{\circ}$ & $110^{\circ}$ & $130^{\circ}$ & $150^{\circ}$ \\
\hline$\left|\frac{g_{1}}{g_{2}}\right|$ & 3630.25 & 158.47 & 39.05 & 15.77 & 8.00 & 4.60 & 2.85 & 1.85 \\
\hline
\end{tabular}

同表にみる如く $g_{2}$ なる極值は理論上存在するといら程度で物標選択上の基準としては極めて不 適で問題にならなら。

次江測点 $P$ K於て $g_{1}$ 老満足する物標 $B$ をとりらるをめとは $\beta<\theta+\gamma$ をる条件が成立しな ければならない。今 $\theta+\gamma=\beta$ 索る限界点を求めてみると $\gamma=\cot ^{-1} \frac{\frac{l^{\prime}}{l}-\cos \theta}{\sin \theta}$ なるにより $60^{\circ}-\frac{2 \theta}{3}=\cot ^{-1} \frac{\frac{l^{\prime}}{l}-\cos \theta}{\sin \theta}$ 即与 $\frac{l^{\prime}}{l}=\sin \theta \cdot \cot \left(60^{\circ}-\frac{2 \theta}{3}\right)+\cos \theta$ 之上り各 $\theta$ 飞対する $\frac{l^{\prime}}{l}$ を Table 4 に示した。

Table 4

\begin{tabular}{|c|c|c|c|c|c|c|c|c|c|}
\hline$\theta$ & $10^{\circ}$ & $20^{\circ}$ & $30^{\circ}$ & $40^{\circ}$ & $50^{\circ}$ & $60^{\circ}$ & $70^{\circ}$ & $80^{\circ}$ & $89^{\circ}$ \\
\hline$l^{\prime}$ & 1.11 & 1.26 & 1.46 & 1.74 & 2.17 & 2.88 & 4.31 & 8.60 & 85.94 \\
\hline
\end{tabular}

（5） $\alpha ， \beta ， \theta$ が変数にして $\gamma$ が常数なるとを $\theta$ の如何に拘ら亦 $g$ が等值をとる条件索求 めてみよう.

$k=2 \pi l^{2} \operatorname{cosec} \gamma \Delta \alpha \Delta \beta\left(=\right.$ 一定)， $m=\sin ^{2} \gamma+2 k \cos \gamma$ 亡和けば. 求むる $\alpha, \beta$ は $\sin ^{-1} \sqrt{\frac{m+\sqrt{m^{2}-4 k^{2}}}{2}}, \sin ^{-1} \sqrt[3]{\frac{m-\sqrt{m^{2}-4 k^{2}}}{2}}$ Kして且つ $\alpha+\beta=180^{\circ}-\gamma$ を满足するる のである. 今問題を簡単にして $\alpha=\beta$ の場合を考えると 上式より $\alpha=\beta=90^{\circ}-\frac{\gamma}{2}$ Kて $g=\frac{\cos ^{2} \frac{\gamma}{2}}{2 \pi l^{2} \operatorname{cosec} \gamma \Delta \alpha \Delta \beta}$ (二一定) となる.

\section{VI. 直線上にとるのと折線状にとるのとの平衡点}

一直線上に三物標をとつそ場合確率密度の極大とまるのは $\alpha=\beta=60^{\circ}$ の場合でそのときの $g=\frac{\frac{3 \sqrt{3}}{8}}{2 \pi l^{2} \Delta \alpha \Delta \beta}$ であつた. 又点 $P$ 飞於て物標 $M A, B, C$. Fig. 7 の如く折線状々とつた場 合, $\theta, \gamma$ が常数で $\alpha, \beta$ が変数なるとき $g$ が最大值をとるのは $\alpha=\beta=60^{\circ}+\frac{\theta}{3}$ Kして $g=\frac{\sin ^{3}\left(60^{\circ}+\frac{\theta}{3}\right) \sin \gamma}{2 \pi l^{2} \Delta \alpha \Delta \beta \sin (\gamma+\theta)}$ であつた。この両 $\mathrm{g}$ が等値をとる朆合の $\gamma$ 換言すれば $\frac{l^{\prime}}{l}$ を求めて

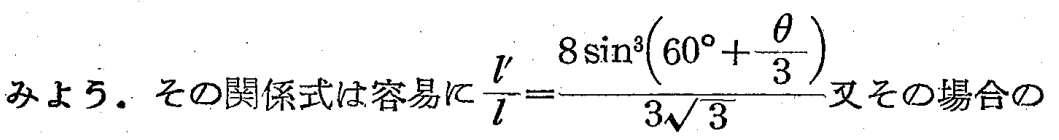
$\gamma=\cot ^{-1}\left\{\frac{8 \sin ^{3}\left(60^{\circ}+\frac{\theta}{3}\right)-3 \sqrt{3} \cos \theta}{3 \sqrt{3} \sin \theta}\right\}$ として得られる。 その結果を Table 5 k示した, 
Table 5

\begin{tabular}{|c|c|c|c|c|c|c|c|c|c|c|c|c|c|c|c|}
\hline$\theta$ & $10^{\circ}$ & $20^{\circ}$ & $30^{\circ}$ & $40^{\circ}$ & $50^{\circ}$ & $60^{\circ}$ & $70^{\circ}$ & $80^{\circ}$ & $90^{\circ}$ & $100^{\circ}$ & $110^{\circ}$ & $120^{\circ}$ & $130^{\circ}$ & $140^{\circ}$ & $150^{\circ}$ \\
\hline$\frac{l^{\prime}}{l}$ & 1.10 & 1.19 & 1.28 & 1.35 & 1.42 & 1.47 & 1.51 & 1.53 & 1.54 & 1.53 & 1.51 & 1.47 & 1.42 & 1.35 & 1.28 \\
\hline
\end{tabular}

従つて $\frac{l^{\prime}}{l}$ が上表の如き值をとるとき折線状に物標を選是するも一值線上ととるも両最大值は等 しくなる。

（註） Table 5 ス於て $\sin ^{3}\left(60^{\circ}+\frac{\theta}{3}\right)=\sin ^{3}\left(60^{\circ}+\frac{180^{\circ}-\theta}{3}\right)$ なる故 $\frac{l^{\prime}}{l}$ の值は $90^{\circ}$ を夾んで対 称である。

以上の事より最る好条件である $\theta=90^{\circ}, \alpha=\beta=90^{\circ}$ の場合でる $\frac{l^{\prime}}{l}=1.54$ にすを゙ない.ま して $P$ 上り $B C, A C$ に至る巨離が共に $l^{\prime}$ なる場合の $g$ の最大值 $\frac{1}{2 \pi l^{2} \Delta \alpha \Delta \beta}$ ¿ $P$ ょり 巨離が $l$ なる直線上に三物標を選んだ $g$ の最大 $\frac{\frac{3 \sqrt{3}}{8}}{2 \pi l^{2} \Delta \alpha \Delta \beta}$ と此較すれば禹者が等しくなるの

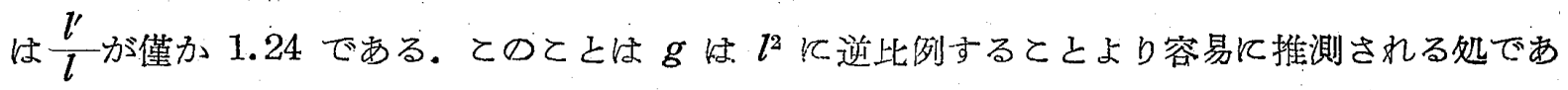
るが充分留意したん点である。

\section{VII. 交刃方位法（羅針儀による）との比較}

（1）物標が一定直線上に存在する場合

或る測点に於て一定直線上に無数に存在する物標よ方任意に選択し 5 るして二本の交文方

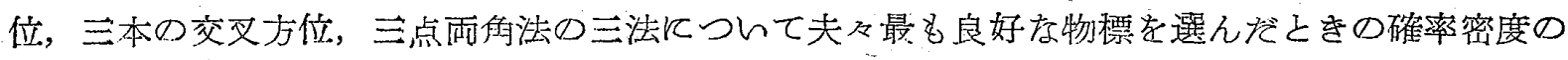
比は $\frac{0.6495}{(\Delta \theta)^{2}}: \frac{0.9164}{(\Delta \theta)^{2}}: \frac{0.6495}{\left(\Delta \theta^{\prime}\right)^{2}}$ 即ち $1: 1.4:\left(\frac{\Delta \theta}{\Delta \theta^{\prime}}\right)^{2}$ 《て表はされる。( $\Delta \theta, \Delta \theta^{\prime}$ は両法に 於ける角度嚜差を示す） ことに $\Delta \theta, \Delta \theta^{\prime}$ には測角誤差の外飞実際海図上に画かれる場合の記入

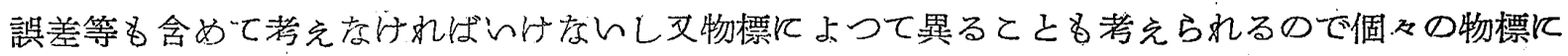
ついての実測譟差の此較は困難で今後の問題として残されるのであるが， $\frac{\Delta \theta}{\Delta \theta^{\prime}}$ は少くとも2以上 之推量される.（今仮に $\frac{\Delta \theta}{\Delta \theta^{\prime}} 2$ としてみると三本の交叉位て上る船位の 3 倍, 二本の場合の 4

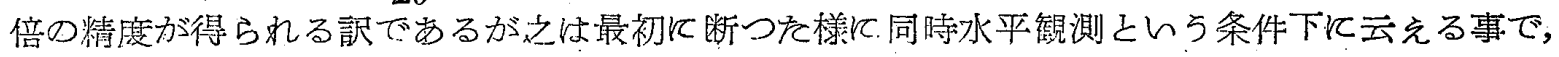
航行中の昜合には測点移動飞基因する誤差，又斜角を測つを場合には当然誤差が含季れ，此等は 偶成性の\&の亡性筫学異江する)

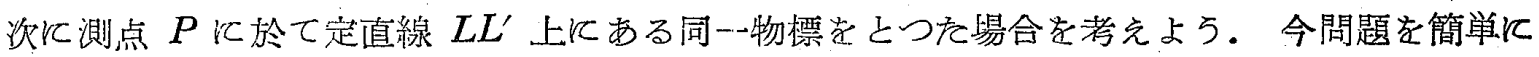
するをめに $P B \perp L L, P A=P C$ 疗る三物標 $A, B, C$ 飞方交方位, 三点両角, 二物標 $A$,

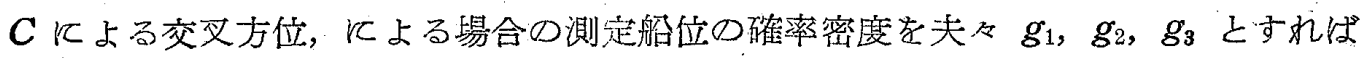
$g_{1}: g_{2}: g_{3}=\sqrt{2+4 \cos ^{4} \alpha}: 2 \sin ^{2} \alpha\left(\frac{\Delta \theta}{\Delta \theta^{\prime}}\right)^{2}: 2 \cos ^{2} \alpha$ 亿て表はされる. 但し $\alpha=\angle A P B=\angle C P B$ ことに $\sqrt{2+4 \cos ^{4} \alpha}>2 \cos ^{2} \alpha$ なる故常に $g_{1}$ は $g_{3}$ より大である。今 $g_{1}=g_{2}$ となる点を求めて みると $\sin \alpha=\sqrt{\frac{\sqrt{6 p^{4}-2}-2}{2\left(p^{4}-1\right)}}$ を得る。但し $p=\frac{\Delta \theta}{\Delta \theta^{\prime}}$ 之より $p$ が 2 なら゙ $\alpha=30^{\circ} 26^{\prime}, p$ が 2.5 
ならば $\alpha=24^{\circ} 39^{\prime}$ である.この值は $p$ Kよつて勿論変るので数值てのものには大した意味はな

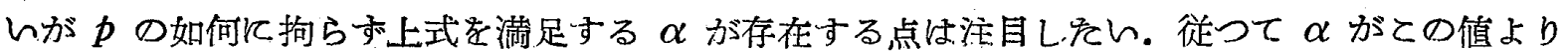
小なるとをは $g_{1}>g_{2}$, 大なるとさは $g_{1}<g_{2}$

（2）物標が同一円周上佀ある場合

二本の交叉方位, 三本の交叉方位，三点両角法に於ける最良の物標を選九だ場合の確率復度の 此は $2: 3: 3 \sqrt{3}\left(\frac{\Delta \theta}{\Delta \theta^{\prime}}\right)^{2}$

(3) 測点が物標の存在する二線分の二等分線上にある場合.

最良の二本の交丈方位法と三点両角法の此は $1:\left(\frac{\Delta \theta}{\Delta \theta^{\prime}}\right)^{2}$

\section{VIII. あ と が き}

以上三点両角法に於ける物標選択法の大要を述べをのであるが,ててに留意しなければならな ん点は先に述べを如く選択物標が限定されを場合交叉方位法に劣ることがあり得る事及び余分な 系統誤差を含まない様にしなければ精測を目的とする本法の主旨に反する事が起りらるといらて とである. 従つて測者と同一水平面上飞あらざる二物標間の夾解測つた場合は水平角に改める 様心掛けそh点である。その外測点移動に基因するる誤差をなくする為には静止状態に於て或は同

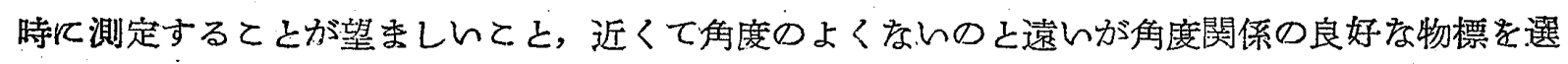
び5る場合には本文に述べた如く lの自乗として影響するてと念頭に和んて選択すべき事等で ある. 斯く考えて行くと非常に厄介な方法であるが特に精測を必要とする場合に用いられるので あるから特別の考虑を払らてとが望ましん。

\section{女献}

1) 觹島 ： 船位の確らしさが等しい点の軌跡について 日航会誌 11 (1954)

2) 平岩：三点雨角法について 日航会誌 9 (1953)

3）平岩：交叉方位法に関する一考察 日航会誌 11 (1954) 